\title{
The effect of topical application of Stryphnodendron adstringens (Martius) Coville extract and oral biotin supplementation on recovery of wounds from digital dermatitis surgery
}

\author{
Aplicação tópica do extrato da casca do barbatimão Stryphnodendron \\ adstringens (Martius) Coville associada à administração oral de \\ biotina na reparação de feridas cirúrgicas de dermatite digital bovina
}

\author{
Luiz Antônio Franco da Silva ${ }^{1}$; Valcinir Aloisio Scalla Vulcani ${ }^{*}$; \\ Rogério Elias Rabelo ${ }^{2}$; Fernanda Figueiredo Mendes 3 ; \\ Sabrina Lucas Ribeiro de Freitas ${ }^{4}$; Jessica Alves da Silva ${ }^{5}$
}

\begin{abstract}
Digital dermatitis can impair the health and milk yield of dairy cattle. Treatment of digital dermatitis involves corrective trimming and footbaths. The results of these are not always satisfactory, with an added risk of persisting residues in the dairy products and environment. In this study, we evaluated the effect of Stryphnodendron adstringens (Martius) Coville extract (applied via footbath or directly over the lesions) and biotin supplementation on wound healing in 90 surgically-corrected digital dermatitisaffected dairy cows. All animals were female, crossbred (Holstein $\times$ Gir), affected with digital dermatitis to different degrees of severity. The lesions were evaluated over a 45-day post-surgical period, and the cows were divided to six treatment groups. The groups were divided based on application of the extract as a footbath solution with or without supplemental biotin, application by brushing with or without biotin, and cleaning with water with or without biotin. The evaluation was performed considering the rates and recovery times. Supplementation with biotin did not influence the rate or recovery time of the surgical wounds. Topical application of the bark extract (via footbath solution and brushing) was determined to be more beneficial than washing with water.
\end{abstract}

Key words: Bovine, lameness, digital illness, phytotherapy, vitamin

\section{Resumo}

A dermatite digital compromete a saúde e produtividade dos bovinos. O controle da enfermidade pode ser feito com a apara corretiva do casco e passagem dos animais em pedilúvio. Os resultados nem sempre são satisfatórios e há o risco de ocorrerem resíduos na carne, leite e no ambiente. No presente estudo avaliou-se a reparação de feridas cirúrgicas de dermatite digital após aplicação tópica do extrato

${ }^{1}$ Prof. Associado, Escola de Veterinária e Zootecnia, Universidade Federal de Goiás, UFG, Goiânia, GO, Brasil. E-mail: prof_ufg. dmv@hotmail.com

2 Profs. Adjuntos, Universidade Federal de Goiás/Regional Jataí, UFG, Jataí, Goiás, GO, Brasil. E-mail: aloisiosv@hotmail.com; rabelovet@yahoo.com.br

${ }^{3}$ Discente de Doutorado do Programa de Pós-Graduação em Ciência Animal, Escola de Veterinária e Zootecnia, Universidade Federal de Goiás, UFG, Goiânia, GO, Brasil. E-mail: nanda_vt@yahoo.com.br

${ }^{4}$ Discente de Mestrado do Programa de Pós-Graduação em Ciência Animal, Escola de Veterinária e Zootecnia, UFG, Goiânia, GO, Brasil. E-mail: sabrina medvet@hotmail.com

${ }_{5}^{5}$ Discente do Curso de Medicina Veterinária, Escola de Veterinária e Zootecnia, UFG, Goiânia, GO, Brasil. E-mail: jj.syy@ hotmail.com

* Author for correspondence 
da casca de barbatimão, em pedilúvio ou por pincelamento, e suplementação com biotina, em 90 vacas de aptidão leiteira. Todos os animais eram fêmeas, mestiças (Gir x Holandesa) e apresentavam dermatite digital em graus variados. As feridas foram analisadas em vários momentos durante 45 dias. Os animais foram divididos em seis grupos de 15 de acordo com o protocolo. Avaliou-se a aplicação do barbatimão em pedilúvio com ou sem suplementação de biotina, barbatimão por pincelamento com ou sem biotina e limpeza com água sob pressão com ou sem biotina, considerando os índices e os tempos de recuperação. A suplementação com biotina não influenciou os índices nem o tempo de recuperação das feridas cirúrgicas de dermatite digital e o uso tópico do extrato da casca do barbatimão, independente da forma de aplicação, se mostrou benéfico em relação à aplicação de água.

Palavras-chave: Bovino, claudicação, enfermidade digital, fitoterapia, vitamina

\section{Introduction}

Bovine digital dermatitis is an infection of multi-factorial etiology and complex pathogenesis, imposing a large number of productive and economic restrictions on global livestock. The disease is characterized by inflammation of the skin in the palm/plantar or dorsal interdigital space, or even in the border region between the coronary corium and the hoof (EVANS et al., 2011; LEÃO et al., 2005). Based on clinical evolution and severity of the lesions, they can appear proliferative, papillomatous, or verrucous (DEMIRKAN et al., 2000; MAREGA, 2001). The diagnosis is based on a physical examination, and is aided by an inspection of the surrounding environment and laboratory identification of the infectious agent. According to the therapeutic protocol, the infection can be treated with surgery, in association with antibiotic therapy, use of anti-inflammatory agents, and topical application of antiseptics and other healing compounds (CUNHA et al., 2002; SILVA et al., 2007).

A footbath can be administered as a preventive or healing process for digital dermatitis infections (SPEIJERS et al., 2010; TEIXEIRA et al., 2010). However, the sanitizing solutions used do not always result in the complete recovery of animals. Several of these solutions are expensive, their overall therapeutic effect is time consuming, and sometimes leave residues in the flesh, milk, and environment (CUNHA et al., 2002; FERREIRA et al., 2004; GOULART, 2011). Parallel to the surgical treatment of the lesions, adjustments in the anatomical conformation of the hooves could contribute to the recovery of animals (SILVA et al., 2009). This is because the adaptation of such measures helps reestablish the format of the corneal structure, and in adapting to the support surface and increasing the capacity to bear the weight of the animals (GREENOUGH, 2007).

Alternatives such as phytotherapy and biotin supplementation have been implemented in the treatment of digital illnesses (SILVA et al., 2009; SILVA et al., 2010a) to minimize the cost of treatment, increase the efficacy, and decrease the possibility of leaving residues. This therapeutic modality can be implemented in the treatment of several infections and conditions in domestic animals (including those affecting the digits) because of its low cost, decreased production cost, minimal amount of persisting residues in the animal and environment, and better compensation of the final product (BERTOLLO, 2002). Among phyto-therapeutic products used, Stryphnodendron adstringens (Martius) Coville has demonstrated astringent, anti-inflammatory, anti-hemorrhagic, antiseptic, antioxidant, and antimicrobial effects (SOUZA et al., 2007). It contains tannin as an active ingredient (a minimum of 20\%), which imparts an astringent and healing effect on the hoof (PANIZZA et al., 1988). Tannins precipitate the proteins of the injured tissues, forming a protective coating that supports healing, and decreases wound permeability and exudation (BEDI; SHENEFELT, 2002; MARTINS et al., 2003; JORGE NETO et al., 1996). 
Biotin is a water-soluble B complex vitamin, also known as vitamin $\mathrm{H}$, which is essential for the metabolism of protein and carbohydrates (CAMPBELL et al., 2000; HIGUCHI et al., 2004). Biotin acts as an enzymatic cofactor in the cellular metabolism of amino acids and in fatty acid synthesis. It also participates in the ruminal fermentation of dietary carbohydrates, converting propionic acid to glucose (in the liver). The primary biotin reaction involves $\mathrm{CO}_{2}$ fixation (carboxylation) in the synthesis of oxaloacetic acid, by conversion of malic acid to pyruvic, propionic, and succinic acid, oxalosuccinic acid conversion to $\alpha$-ketoglutaric acid, and synthesis of malonyl-CoA. Biotin is also an initial substrate for the synthesis of fats and carbamoyl phosphate. In the urea cycle, biotin performs an important role in the synthesis of proteins and purines, metabolism of nucleic acids, and the deamination of amino acids. It also plays an important role in the control of production rate and deposition of proteins like keratin, and is essential for the normal differentiation of the epidermal tissue (aiding in the formation of skin and tissues), and for keratinization of the hoof and horn (CAMPBELL et al., 2000; FITZGERALD et al., 2000; HIGUCHI et al., 2004; KORNEGAY, 1986; ZIMMERLY; WEISS, 2001). Supplementation with biotin promotes greater growth (than wear) on the hoof (SILVA et al., 2010a) and assists in the healing and prevention of digital diseases in several species of animals (CAMPBELL et al., 2000; FITZGERALD et al., 2000; KORNEGAY, 1986; RANDHAWA et al., 2008). Biotin is reported to improve milk production and composition in dairy bovines, increase the fertility of cows (FITZGERALD et al., 2000; HIGUCHI et al., 2004; SEYMOUR, 2001; ZIMMERLY; WEISS, 2001), and aid in maintaining the health of hooves in beef cattle (CAMPBELL et al., 2000). However, as the biotin is synthesized by ruminal bacteria, several aspects can influence its production, such as the elevated supply of concentrated food, stress, and metabolic issues; this interferes in the functioning of ruminal microbes, occasionally leading to acidosis, thus reducing the synthesis of vitamins in the rumen (BERGSTEN; MULLING, 2004; SILVA et al., 2010a).

The aim of this study was to evaluate the topical action of the Stryphnodendron adstringens bark extract (Stryphnodendron adstringens (Martius) Coville) associated with the oral use of biotin and with the surgical treatment of lesions, when used as a co-adjuvant for the healing of digital dermatitis wounds in dairy cows.

\section{Material and Methods}

The study was performed between April 2010 and October 2011 on a rural dairy farm in the city of Trindade (Goiás, Brazil). The dry seasons of the year (low rainfall) were taken into account when performing surgery for the treatment of illnesses. The survey was approved by the Comitê de Ética em Pesquisa (Research Ethics Committee) of the Federal University of Goiás, under the protocol number 150/2010. Necessary precautions were taken to minimize any alterations in management that could intensify the discomfort of the animals.

We evaluated 90 cows from a livestock facility with a total herd of 700 dairy cows at a reproductive stage, expressing clinical signs of digital dermatitis. The established experimental methodology was adapted to the daily routine of the livestock facility in order to minimize the interference with the usual activities performed on the farm. During the trial period, the bovine subjects were placed in a field of approximately 10 hectares, with an abundance of Brachiaria decumbens, natural shadow and shade, supply of water (Australian water cooler type), and a mineralized salt lick. The animals were semi-intensively handled, and received daily supplementation with corn silage and concentrate (Performance Leite $^{\circledR}$; Boiforte, Goiás, Brazil), divided over the two daily meals offered after the milking process. 
All animals employed in the survey were lactating females, crossbred (Holstein $\times$ Gir), of varied ages and weights, identified by ear tags, and divided into six groups of 15 animals (GI, GII, GIII, GIV, GV, and GIV). The digital lesions were surgically treated as per the protocols described by Silva et al. (2007), and the digital corneal case measures adjusted with the aid of a manual grinder $\left(\mathrm{BOSCH}^{\circledR}\right.$ Modelo 7081-5; Bosch Ltd., Stuttgart, Germany). A topical application of methyl salicylate, iron perchlorate, and metallic iodine (Hemosthal, Minerthal Produtos Agropecuários Ltd., São Paulo, Brazil) was applied immediately after surgery. This was followed by an application of oxytetracycline hydrochloride powder (Terramycin soluble powder with Antigerm 77; Pfizer, New York City, NY, USA). The wound was protected with hydrophilic cotton and sprayed with copper sulfate (Boiforte). The orthopedic bandages were made to overlap and were coated with a product composed of dichlorodivynylpyrrolidone (DDPV), orthoortho-dimethyl-para-nitrophenyl phosphorothioate, and sterilized wood tar (Miosthal; Minerthal Produtos Agropecuários Ltda., São Paulo, Brazil). The subjects were subjected to parenteral antibiotic therapy every 48 hours with oxytetracycline dihydrate (Oxitetra 20\% LA; Agener União Ltda., Minas Gerias, Brazil), from the day of surgery to the completion of three applications (SILVA et al., 2007).

The bandages were removed 7 days postsurgery, when the hooves of the animals were subjected to a footbath containing a $10 \%$ Stryphnodendron adstringens glycolic extract (Stryphnodendron adstringens extract; Farmogral, Distrito Federale, Brazil), or brushed with the same solution, depending on the group to which the animal belonged. Regardless of the year in which the animal was treated, the digital lesions were observed immediately following surgery, during a 45-day post-surgical period, during which time, in theory, the complete clinical recovery of the animals should have occurred. The evaluation of the lesions conducted immediately after the surgical curettage was considered as the zero moment (M0). The subsequent observations were conducted on the seventh (M1), 15th (M2), 30th (M3) and 45th days (M4) after surgical treatment. The parameters evaluated were: hemorrhage, exudate presence, crust presence, re-epithelialization, recrudescent process, and other complications as myiasis and arthritis. A clinical evaluation of the wounds helped determine whether the animals had recovered or not. Based on the recommendations by Bergsten et al. (2003), the diet for each animal was supplemented with $20 \mathrm{mg}$ of biotin (Performance Leite ${ }^{\circledR}$; Boiforte), equally distributed among the two daily meals, depending on the group to which the animals belonged. The biotin was added to the concentrated food and supplied to the animals in individual troughs, ensuring ingestion, with particular notice of the total emptying of troughs.

During the treatment and established times for wound evaluation after surgery, the animals were kept in a stock pen, and the affected digit raised with rope. The hooves were cleaned with water, under pressure, and the dirt removed manually. The surgical wounds on the animals in the GI group were treated with Stryphnodendron adstringens solution in a wooden footbath (width approximately $80 \mathrm{~cm}$ for every $10 \mathrm{~m}$ length), divided out of a masonry foot-washing container of $3 \mathrm{~m}$ length, with a $2 \mathrm{~m}$ ramp sloping $2 \%$ towards the foot washing tank, and a treatment container $(3 \mathrm{~m})$. The depth of each container, including the protection walls, was $40 \mathrm{~cm}$. Half-meter ramps were provided at the entrance and exit of the tanks. Two hundred liters of the Stryphnodendron adstringens glycolic extract solution was added at a final concentration of $10 \%$ (Stryphnodendron adstringens extract (Martius) Coville; Farmogral) for treatment. The solution was prepared 20 minutes prior to the passage of animals through the footbath. The animals were made to stay in the footbath for 2 minutes; this treatment was performed daily for 45 days. The solution was changed every 72 hours (after three passages). 
Twenty animals were estimated to be submitted to the footbath daily, therefore totaling 60 animals prior to each solution change.

The lesions on the cows allocated to the GII group were treated with the same protocol as for GI; however, the animals were not provided with the biotin supplement. The same phytotherapeutic strategy was employed on the subjects of the GIII group. However, the method of application differed; $50 \mathrm{~mL}$ of the solution was applied by brushing onto the wound, daily, for 45 days. After application, the digit was suspended for two minutes after which the animal was released. This group was supplemented with previously established quantities of biotin. The surgical wounds in the animals of the GIV group were medicated with the 10\% Stryphnodendron adstringens extract as per the protocols followed for the GIII group; however, the animals did not receive the biotin supplement. The bovines distributed in the GV group did not receive any topical treatment, but were provided with the biotin supplement. The animals allocated to the GVI group did not receive any treatment (topical or supplement) (Table 1).

BIOESTAT 5.0 software was used for statistical analysis. The recovery indexes were evaluated based on the supplementation with biotin, treatment with Stryphnodendron adstringens, and the method of application, by Fischer Exact test $(\mathrm{p}<0.05)$. The Odds Ratio was calculated for the comparison between groups.

Table 1. Therapeutic protocols applied to the different experiment groups.

\begin{tabular}{|c|c|c|c|c|c|}
\hline \multirow[t]{2}{*}{ GROUP } & \multirow[t]{2}{*}{ No. of animals } & \multicolumn{2}{|c|}{$\begin{array}{c}\text { STRYPHNODENDRON } \\
\text { ADSTRINGENS }\end{array}$} & \multirow{2}{*}{$\begin{array}{c}\text { BIOTIN } \\
\text { Oral }\end{array}$} & \multirow{2}{*}{$\begin{array}{c}\text { WATER } \\
\text { Pressurized }\end{array}$} \\
\hline & & Footbath & Brushing & & \\
\hline I & 15 & + & - & + & + \\
\hline II & 15 & + & _ & - & + \\
\hline III & 15 & - & + & + & + \\
\hline IV & 15 & _ & + & _ & + \\
\hline $\mathbf{V}$ & 15 & _ & _ & + & + \\
\hline VI & 15 & _ & _ & - & + \\
\hline
\end{tabular}

\section{Results}

Table 2 lists the percentage of recovered animals, and presents the statistical comparison between the groups and methods of treatment. A statistical difference was observed between GI and GV, GI and GVI, GII and GVI, GIII and GV, GIII and GVI, GIV and GV, and GIV and GVI. The comparisons between GI and GV and GIII and GV indicated that the biotin did not influence the recovery of the animals. The limiting factor for the percentage of recovery in animals was the topical application of Stryphnodendron adstringens, regardless of the means of application. A comparison between GI and GVI revealed the importance of Stryphnodendron adstringens in the recovery of animals, and that the biotin may have influenced the healing. The influence of Stryphnodendron adstringens has been ratified in the comparison between GII and GVI. Based on a comparison between GIV and GV, the supplementation with biotin was verified to not influence recovery in the animals. This was based on the observation that treatment with Stryphnodendron adstringens without biotin supplementation showed a higher recovery rate. This fact was reiterated by the comparison between groups treated with Stryphnodendron adstringens and not treated with topical application (comparison between GIV and GVI). 
Table 2. Comparison of clinical recovery rates among the groups using the Fisher's Exact Test and Odds Ratio.

\begin{tabular}{|c|c|c|c|c|c|c|}
\hline Comparison & Groups & Recovered & $\%$ & $p^{*}$ & Odds & $p^{* *}$ \\
\hline \multirow[t]{2}{*}{1} & $\mathrm{GI}^{\mathrm{A}}$ & $13 / 15$ & 86.66 & 0.235 & 3.25 & 0.388 \\
\hline & $\mathrm{GIII}^{\mathrm{A}}$ & $10 / 15$ & 66.66 & & & \\
\hline \multirow[t]{2}{*}{2} & $\mathrm{GI}^{\mathrm{A}}$ & $13 / 15$ & 86.66 & 1 & 0.4643 & 1 \\
\hline & GIII $^{\mathrm{A}}$ & $14 / 15$ & 93.33 & & & \\
\hline \multirow[t]{2}{*}{3} & $\mathrm{GI}^{\mathrm{A}}$ & $13 / 15$ & 86.66 & 1 & 1.625 & 1 \\
\hline & $\mathrm{GIV}^{\mathrm{A}}$ & $12 / 15$ & 80 & & & \\
\hline \multirow[t]{2}{*}{4} & $\mathrm{GI}^{\mathrm{A}}$ & $13 / 15$ & 86.66 & 0.0025 & 17.87 & 0.0032 \\
\hline & $\mathrm{GV}^{\mathrm{B}}$ & $4 / 15$ & 26.66 & & & \\
\hline \multirow[t]{2}{*}{5} & $\mathrm{GI}^{\mathrm{A}}$ & $13 / 15$ & 86.66 & 0.0007 & 26 & 0.0010 \\
\hline & $\mathrm{GVI}^{\mathrm{B}}$ & $3 / 15$ & 20 & & & \\
\hline \multirow[t]{2}{*}{6} & $\mathrm{GII}^{\mathrm{A}}$ & $10 / 15$ & 66.66 & 0.1686 & 0.1429 & 0.1709 \\
\hline & $\mathrm{GIII}^{\mathrm{A}}$ & $14 / 15$ & 93.33 & & & \\
\hline \multirow[t]{2}{*}{7} & $\mathrm{GII}^{\mathrm{A}}$ & $10 / 15$ & 66.66 & 0.6817 & 0.5 & 0.6797 \\
\hline & GIV $^{\mathrm{A}}$ & $12 / 15$ & 80 & & & \\
\hline \multirow[t]{2}{*}{8} & $\mathrm{GII}^{\mathrm{A}}$ & $10 / 15$ & 66.66 & 0.0656 & 5.5 & 0.0673 \\
\hline & $\mathrm{GV}^{\mathrm{A}}$ & $4 / 15$ & 26.66 & & & \\
\hline \multirow[t]{2}{*}{9} & $\mathrm{GII}^{\mathrm{A}}$ & $10 / 15$ & 66.66 & 0.0253 & 8 & 0.0271 \\
\hline & $\mathrm{GVI}^{\mathrm{B}}$ & $3 / 15$ & 20 & & & \\
\hline \multirow[t]{2}{*}{10} & $\mathrm{GIII}^{\mathrm{A}}$ & $14 / 15$ & 93.33 & 0.5977 & 3.5 & 0.5912 \\
\hline & $\mathrm{GIV}^{\mathrm{A}}$ & $12 / 15$ & 80 & & & \\
\hline \multirow[t]{2}{*}{11} & $\mathrm{GIII}^{\mathrm{A}}$ & $14 / 15$ & 93.33 & 0.0005 & 38.5 & 0.0008 \\
\hline & $\mathrm{GV}^{\mathrm{B}}$ & $4 / 15$ & 26.66 & & & \\
\hline \multirow[t]{2}{*}{12} & $\mathrm{GIII}^{\mathrm{A}}$ & $14 / 15$ & 93.33 & 0.0001 & 56 & 0.0002 \\
\hline & $\mathrm{GVI}^{\mathrm{B}}$ & $3 / 15$ & 20 & & & \\
\hline \multirow[t]{2}{*}{13} & GIV $^{\mathrm{A}}$ & $12 / 15$ & 80 & 0.0092 & 11 & 0.0104 \\
\hline & $\mathrm{GV}^{\mathrm{B}}$ & $4 / 15$ & 26.66 & & & \\
\hline \multirow[t]{2}{*}{14} & GIV $^{\mathrm{A}}$ & $12 / 15$ & 80 & 0.0028 & 16 & 0.0035 \\
\hline & $\mathrm{GVI}^{\mathrm{B}}$ & $3 / 15$ & 20 & & & \\
\hline \multirow[t]{2}{*}{15} & $\mathrm{GV}^{\mathrm{A}}$ & $4 / 15$ & 26.66 & 1 & 1.4545 & 1 \\
\hline & $\mathrm{GVI}^{\mathrm{A}}$ & $3 / 15$ & 20 & & & \\
\hline
\end{tabular}

$\mathrm{p}^{*}=\mathrm{p}$ value of the Fisher's Exact Test

$\mathrm{p}^{* *}=\mathrm{p}$ value of the Odds Ratio

$\mathrm{A}$ and $\mathrm{B}$ differ statistically between columns.

The data was also grouped, dividing the animals that were supplemented with biotin and those that were not. No differences were observed between the animals that ingested biotin in the diet and those that did not, irrespective of treatment with Stryphnodendron adstringens in a footbath, by brushing, or without topical treatment (Table
3). Table 4 displays and compares the clinical recovery rates between the animals treated with Stryphnodendron adstringens that received the biotin and those that did not. It was verified that biotin did not influence recovery in animals treated with Stryphnodendron adstringens. 
Table 3. Comparison of clinical recovery rates between the animals supplemented with, and not supplemented with, biotin, using the Fisher's Exact Test and Odds Ratio.

\begin{tabular}{|c|c|c|c|c|c|c|}
\hline Comparison & Groups & Recovered & $\%$ & $p^{*}$ & Odds & $p^{* *}$ \\
\hline Received Biotin ${ }^{A}$ & GI, GIII and GV & $31 / 45$ & 68.88 & 0.202 & 1.771 & 0.277 \\
\hline Did not receive Biotin ${ }^{4}$ & GII, GIV and GVI & $25 / 45$ & 55.55 & & & \\
\hline
\end{tabular}

$\mathrm{p}^{*}=\mathrm{p}$ value of the Fisher's Exact Test

$\mathrm{p}^{* *}=\mathrm{p}$ value of the Odds Ratio

A and B differ statistically between columns.

Table 4. Comparison of clinical recovery rates between animals treated with Stryphnodendron adstringens extract supplemented (or not) with biotin, using the Fisher's Exact Test and Odds Ratio

\begin{tabular}{cccccc}
\hline Comparison & Recovered & $\boldsymbol{\%}$ & $\boldsymbol{p}^{*}$ & Odds & $\boldsymbol{p}^{* *}$ \\
\hline Stryphnodendron adstringens with Biotin (GI and GIII) & $27 / 30$ & 90 & 0.1112 & 3.2727 & 0.1820 \\
Stryphnodendron adstringens without Biotin $($ GII, GIV) & $22 / 30$ & 73.33 & & & \\
\hline
\end{tabular}

$\mathrm{p}^{*}=\mathrm{p}$ value of the Fisher's Exact Test

$\mathrm{p}^{* *}=\mathrm{p}$ value of the Odds Ratio

$\mathrm{A}$ and $\mathrm{B}$ differ statistically between columns.

\section{Discussion}

The antimicrobial and anti-inflammatory action of tannin existing in the Stryphnodendron adstringens extract is believed to contribute to the increase in recovery indices and decrease in time taken for wound healing, thereby justifying the implementation of this phytotherapy strategy. These effects are advantageous in relation to cleaning solely with water (GV and GVI). Silva et al. (2010b) have affirmed the Stryphnodendron adstringens to express anti-inflammatory, antimicrobial, and healing effects. This explains, in part, its positive effect on the recovery of digital dermatitis lesions. Lima (2010) evaluated the action of Stryphnodendron adstringens on cutaneous wounds in rabbits, and observed that the product promoted fibroblast activation, early development in the conjunctive tissue, tissue re-epithelialization, and neovascularization, clearly favoring the healing process.

It may be possible that the breed group, animal category, rearing system, surgical treatment of lesions, the vehicle employed for application of the Stryphnodendron adstringens extract, and nutritional management are of greater significance for recovery, than the method of phytotherapy. Silva et al. (2009) implemented a similar therapeutic protocol for the treatment of bovine digital dermatitis, with different kinds of clinical presentation, and obtained positive results in the same. However, in this study, the method of application of the Stryphnodendron adstringens extract (brushing or footbath) did not significantly affect the recovery indices. This reinforced the theory presented in this paper.

Although the method of application did not influence healing of the surgical wounds, brushing of the Stryphnodendron adstringens extract on the wounds could be beneficial in specific situations, such as the lack of a footbath at the farm, or when a low number of animals are affected with digital infections. However, we contend that the protocol adopted here is not absolute. Therefore, new possibilities should be explored in the use of Stryphnodendron adstringens for the treatment of digital diseases. One of the possibilities would be a topical application of this phytotherapy following the surgical treatment of the lesions, and, also, in the prophylaxis and in the control of these diseases. 
Several publications have indicated supplementation with biotin to be a beneficial for hoof growing, increase in resistance, and prevention of digital diseases. Silva et al. (2010a) observed higher corneal case growth and resistance in young bovines of the Girolando breed supplemented with this vitamin. Bergsten et al. (2003) observed the positive effect of biotin supplementation on the production of milk, and the reduction of digital lesions in dairy cows. Randhawa et al. (2008) evaluated the intensity and prevalence of several digital lesions in a single group of dairy cows prior to and after supplementation with biotin. These researchers proposed the prevention and treatment of foot lesions with biotin to be due to its participation in protein synthesis, which enhances the keratinization of epidermal adnexa, including the hoof corneal case. The authors observed a reduction in the numbers of less-intense lesions (caused by hoof erosion), lesions typically associated with digital dermatitis, following supplementation with biotin. However, in the more severe cases of hoof erosion, no difference was observed between the groups with our without biotin supplementation.

In addition, the negative results obtained in biotin-supplemented animals may be attributed, in part, to the accentuated degree of intensity of the lesions. However, despite the production of a better quality corneal tissue due to biotin, the environmental hygiene conditions to which the animals were exposed remained unchanged. A similar justification was presented by Randhawa et al. (2008) upon observation that the supplementation with biotin did not influence recovery of the more severe lesions in the hoof; however, the authors did not relate this to the deficit in environmental hygiene. The period during which the animals were supplemented with biotin must also be considered. Zenker et al. (1995) conducted a similar analysis on 42 stallions of the Lipizzaner breed (equine species), observing that providing the animals with biotin supplements for 19 to 33 months improved the mechanical resistance of the animal hooves, with emphasis on the more sensitive structures such as the white lines. Experiments concerning biotin supplementation are more extensive in equines, and the shortage of studies in bovines leaves a gap in the actual knowledge of its effects on the development of bovine hooves. However, it can be noted that biotin must be ingested for longer periods in order to affect tissue healing or growth.

The diet of corn silage and concentrate supplied to the cows may also have influenced biotin action. Under these circumstances, the bulk/concentrate, associated to the $\mathrm{pH}$ and size of the particles, could contribute to the acidification of the ruminal environment in varied intensities, resulting in a dynamic alteration of the ruminal microbial population. This may result in a decrease in the number of protozoans and bacterial producers of biotin, and an increase in the bacterial consumers of biotin, leading to lower usage of the supplemented vitamin. Santschi et al. (2005) proposed similar arguments, adding that biotin can be destroyed by the physiochemical characteristics of the ruminal environment.

\section{Conclusion}

The topical application of the Stryphnodendron adstringens extract, via brushing onto the hoof or footbath, increased the healing indices of surgical wounds of digital dermatitis. However, the dietary supplementation with biotin as the co-adjuvant treatment did not influence the recovery rates.

\section{Acknowledgements}

The autors gratefully acknowledges the financial support provided by Conselho Nacional de Desenvolvimento Científico e Tecnológico (CNPq) and Fundação de Amparo à Pesquisa do Estado de Goiás (FAPEG). 


\section{References}

BEDI, M. K.; SHENEFELT, P. D. Herbal therapy in dermatology. Archives of Dermatology, Chicago, v. 138, n. 2, p. 2332-242, fev. 2002.

BERGSTEN, C.; GREENOUGH, C. R.; GAY, J. M.; SEYMOUR, W. M.; GAY, C. C. Effects of biotin supplementation on performance and claw lesions on a commercial dairy farm Journal of Dairy Science, Champaign, v. 86, n. 2, p. 3953-3962, 2003.

BERGSTEN, C.; MULling, C. Some reflections on research on bovine laminitis-Aspects of clinical and fundamental research. In: INTERNATIONAL SYMPOSIUM, AND 5TH CONFERENCE ON LAMENESS IN RUMINANTS, 13., 2004, Maribor. Anais... Maribor: B. Zemljic, 2004. p. 53-60. Available at: <http://www.journalofdairyscience.org/article/S00220302(10)70265-4/references >. Accessed at: 20 fev. 2014.

BERTOLLO, V. L. Condicionantes para a adoção da produção mais limpa pelos agricultores familiares produtores de leite no município de Erval Grande, RS. 2002. Dissertação (Mestrado em Agronegócio)Universidade Regional Integrada do Alto Uruguai e das Missões, Erechim.

CAMPBELL, J. R.; GREENOUGH, P. R.; PETRIE, L. The effects of dietary biotin supplementation on vertical fissures of the claw wall in beef cattle. The Canadian Journal of Veterinary Research, Ottawa, v. 41, n. 9, p. 690-694, set. 2000.

CUNHA, P. H. J.; SILVA, L. A. F.; FIORAVANTI, M. C. S.; BORGES, N. C.; MORAES, R. R.; SANTANA, A. P. Avaliação físico-química e microbiológica de diversas soluções desinfetantes utilizadas em pedilúvio para bovinos. ARS Veterinaria, Jaboticabal, v. 18, n. 2, p. 130136, ago. 2002.

DEMIRKAN, I.; MURRAY, R. D.; CARTER, S. D. Skin diseases of the bovine digit associated with lameness. Veterinary Bulletin, Puławy, v. 70, n. 2, p. 149-171. 2000.

EVANS, N. J.; BLOWEY, R. W.; TIMOFTE, D.; ISHERWOOD, D. R.; BROWN, J. M.; MURRAY, R.; PATON, R. J.; CARTER, S. D. Association between bovine digital dermatitis treponemes and a range of "non-healing" bovine hoof disorders. Veterinary Record, London, v. 168, n. 8, p. 689-696, fev. 2011.

FERREIRA, P. M.; LEITE, R. C.; CARVALHO, A. U.; FACURY-FILHO, E. J.; SOUZA, R. C.; FERREIRA, M. G. Custo e resultados do tratamento das sequelas de laminite bovina: relato de 112 casos em vacas em lactação no sistema free stall. Arquivo Brasileiro de Medicina Veterinária e Zootecnia, Belo Horizonte, v. 56, n. 5, p. 589-594, out. 2004.
FITZGERALD, T.; NORTON, B. W.; ELLIOTT, R.; PODLICH, H.; SVENDSEN, O. L. The influence of long-term supplementation with biotin on the prevention of lameness in pasture fed dairy cows. Journal of Dairy Science, New Yorque, v. 83, n. 2, p. 338-344, fev. 2000.

GOULART, D. S. Detecção de resíduos de soluções sanitizantes empregadas em pedilúvio para bovinos no leite e solo. 2011. Dissertação (Mestrado em Ciência Animal) - Escola de Veterinária e Zootecnia, Universidade Federal de Goiás, Goiânia.

GREENOUGH, P. Bovine Laminitis and Lameness: a hands on approach. St. Louis: Saunders Elsevier, 2007. $328 \mathrm{p}$.

HIGUCHI, H.; MAEDA, T.; NAKAMURA, M.; KUWANO, A.; KAWAI, K.; KASAMATSU, M.; NAGAHATA, H. Effects of biotin supplementation on serum biotin levels and physical properties of samples of solar horn of Holstein cows. The Canadian Journal of Veterinary Research, Ottawa, v. 68, n. 2, p. 93-97, abr. 2004.

KORNEGAY, E. T. Biotin in swine production: A review. Livestock Production Science, Blascksburg, v. 14, n. 1, p. 65-89, jan. 1986.

LEÃO, M. A.; SILVA, L. A. F.; FIORAVANTI, M. C. S.; JAYME, V. S.; SILVA, M.A. M.; CUNHA, P. H. J.; SILVA, O. C.; RABELO, R. E.; SILVA, L. M.; TRINDADE, B. R. Dermatite digital bovina: aspectos relacionados à evolução clínica. Ciência Animal Brasileira, Goiânia, v. 6, n. 4, p. 267-277, 2005.

LIMA, C. R. O. Reparação de feridas cutâneas incisionais em coelhos após tratamento com stryphnodendron adstringens e quitosana. 2010. Dissertação (Programa de Pós-Graduação em Ciência Animal) - Escola de Veterinária, Universidade Federal de Goiás, Goiânia.

MAREGA, L. M. Ocorrência e tratamento de lesões podais semelhantes à dermatite digital em bovinos. 2001. Dissertação (Mestrado em Medicina Veterinária) - Faculdade de Ciências Agrárias e Veterinárias, Universidade Estadual Paulista, Jaboticabal.

MARTINS, P. S.; ALVEZ, A. L. G.; HUSSNI, C. A.; SEQUEIRA, J. L.; NICOLETTI, J. L. M.; THOMASSIAN, A. Comparação entre fitoterápicos de uso tópico na cicatrização de pele em equinos. Archives of Veterinary Science, Curitiba, v. 8, n. 2, p. 1-7, 2003.

JORGE NETO, J.; FRACASSO, J. F.; NEVES, M. C. L. C.; SANTOS, L. E.; BANUTH, V. L. Tratamento de úlcera varicosa e lesões de pele com Calendula officinalis L. e/ou com Stryphnodendron barbatiman (vellozo) martius. Revista de Ciências Farmacêuticas, Araraquara, v. 17, n. 2, p. 181-186, 1996. 
RANDHAWA, S. S.; DUA, K.; RANDHAWA, C. S.; RANDHAWA, C. S.; MUNSHI, S. K. Effect of biotin supplementation on hoof health and ceramide composition in dairy cattle. Veterinary Research Communications, v. 32, p. 599-608, 2008.

PANIZZA, S.; ROCHA; A. B.; GECCHI, R.; SOUZA E SILVA, R. A. P. Stryphnodendron barbatiman (vellozo) martius: teor em tanino na casca e sua propriedade cicatrizante. Revista de Ciências Farmacêuticas, Araraquara, v. 10, n. 2, p. 101-106, 1988.

SANTSCHI, D. E.; BERTHIAUME, R.; MATTE, J. J.; MUSTAFA, A. F.; GIRARD, C. L. Fate of supplementary B-vitamins in the gastrointestinal tract of dairy cows. Journal of Dairy Science, Madison, v. 88, n. 6, p. 2043-2054, 2005.

SEYMOUR, W. M. Biotin, hoof health and milk production in dairy cows. In: ANNUAL RUMINANT NUTRITION SYMPOSIUM, 12., 2001, Florida. Proceedings... Florida: IFAS, 2001. p. 70-78.

SILVA, L. A. F.; EURIDES, D.; PAULA, J. R.; LIMA, C. R. O.; MOURA, M. I. Manual do Stryphnodendron adstringens. Goiânia: Editora Kelps, 2010b. 94 p.

SILVA, L. A. F.; FIORAVANTI, M. C. S.; MOURA, M. I.; SILVA, M A. M.; HELOU, J. B.; FREITAS, S. L. R.; LIMA, C. R. O. Adequação nas medidas do casco associado ao tratamento cirúrgico e aplicação tópica do extrato da casca do stryphnodendron adstringens (Strhypnodendron barbatimam Martius) na recuperação de bovinos da raça Nelore com dermatite digital. In: CONGRESSO BRASILEIRO DE BUIATRIA, 8., 2009, Belo Horizonte. Anais... Goiânia: Ciência Animal Brasileira, 2009. p. 379-385. Suplemento 1.

SILVA, L. A. F.; FRANCO, L. G.; ATAYDE, I. B.; CUNHA, P. H. J.; MOURA, M. I.; GOULART, D. S. Effect of biotin supplementation on claw horn grow in young, clinically healthy cattle. Canadian Veterinary Journal, Ottawa, v. 51, n. 6, p. 607-610, 2010a.
SILVA, L. A. F.; RABELO, R. E.; FIORAVANTI, M. C. S.; SILVA, M. A. M.; MOURA, M. I.; TRINDADE, B. R.; FRANCO, L. G.; SOARES, L. K.; BARBOSA, V. T. Dermatite digital bovina: avaliação de um protocolo terapêutico e cirúrgico para lesões nas fases inicial, erosiva e verrucosa. ARS Veterinaria, Jaboticabal, v. 23, n. 1, p. 23-31, 2007.

SOUZA, T. M.; SEVERI, J. A.; SILVA, V. Y. A.; SANTOS, E.; PIETRO, L. C. L. R. Bioprospecção de atividade antioxidante e antimicrobiana da casca de Stryphnodendron adstringens (Mart.) Coville (Leguminosae - Mimosoidade). Revista de Ciência Farmacêutica Básica Aplicada, Araraquara, v. 28, n. 2, p. 221-226, 2007.

SPEIJERS, M. H. M.; BAIRD, L. G.; FINNEY, G. A.; McBRIDE, J.; KILPATRICK, D. J.; LOGUE, D. N.; O'CONNELL, N. E. Effectiveness of different footbath solutions in the treatment of digital dermatitis in dairy cows. Journal of Dairy Science, Ottawa, v. 93, n. 12, p. 5782-5791, 2010.

TEIXEIRA, A. G. V.; MACHADO, V. S.; CAIXETA, L. S.; PEREIRA, R. V.; BICALHO, R. C. Efficacy of formalin, copper sulfate, and a commercial footbath product in the control of digital dermatitis. Journal of Dairy Science, Ottawa, v. 93, n. 8, p. 3628-3634, 2010.

ZIMMERLY, C.A.; WEISS, W. P. Effects of supplemental dietary biotin on performance of holstein cows during early lactation. Journal of Dairy Science, Ottawa, v. 84, n. 2, p. 498-506, 2001.

ZENKER, W.; JOSSECK, H.; GEYER, H. Histological and physical assessment of poor hoof horn quality in Lipizzaner horses and a therapeutic trial with biotin and placebo. Veterinary Journal, London, v. 27, n. 3, p. 183191, 1995. 